\title{
Immunochemical analysis of the integrin expression in retinal pigment epithelial cells
}

Janosch P Heller ${ }^{1,2,3,{ }^{*}}$, Tristan G Heintz ${ }^{1,4}$, Jessica CF Kwok ${ }^{1,5,6}$, Keith R Martin ${ }^{1,7,8,9,{ }^{*}}$ and James W Fawcett ${ }^{1,6, *}$

1John van Geest Centre for Brain Repair, University of Cambridge, Cambridge CB2 OPY, United Kingdom

${ }^{2}$ Queen Square Institute of Neurology, University College London, Department of Clinical and Experimental Epilepsy, Queen Square House, London WC1N 3BG, United Kingdom

${ }^{3}$ FutureNeuro SFI Research Centre and Department of Physiology \& Medical Physics, Royal College of Surgeons in Ireland, Dublin D02 YN77, Ireland

${ }^{4}$ School of Life Sciences, University of Sussex, Brighton BN1 9QG, United Kingdom

${ }^{5}$ School of Biomedical Sciences, Faculty of Biological Sciences, University of Leeds, Leeds LS2 9JT, United Kingdom

${ }^{6}$ Centre for Reconstructive Neurosciences, Institute of Experimental Medicine, Czech Academy of Science, 14220 Prague 4, Czech Republic

${ }^{7}$ Department of Ophthalmology, NIHR Biomedical Research Centre and Wellcome Trust MRC Cambridge Stem Cell Institute, University of Cambridge, United Kingdom

${ }^{8}$ Centre for Eye Research Australia, Royal Victorian Eye and Ear Hospital, Melbourne, Australia

${ }^{9}$ Ophthalmology, Department of Surgery, University of Melbourne, Melbourne, Australia

*Authors to whom correspondence should be addressed.

janoschheller@rcsi.ie

T.Heintz@sussex.ac.uk

J.Kwok@leeds.ac.uk

keith.martin@unimelb.edu.au

jf108@cam.ac.uk 


\section{Abstract}

Retinal pigment epithelial (RPE) cells have been used in disease modelling and transplantation studies in retinal diseases. Several types of RPE cells have been trialed, ranging from primary cells and immortalized cell lines to stem cell-derived RPE cells. During aging and in disease, the extracellular environment of the RPE cells changes, interfering with RPE cell adhesion. We hypothesize that this could be a key problem in transplantation studies that have reported lack of adhesion and survival of the transplanted RPE cells. Integrins are essential for the proper function of the RPE, mediating adhesion to Bruch's membrane, and the binding and subsequent phagocytosis of photoreceptor outer segments. Variability that has been found in clinical trials might be due to the variability of cell types used and their expression profiles of surface molecules. Here, we set out to analyze integrin expression in primary rat RPE cells and in the human cell line ARPE-19 using immunochemistry. We found that both cell types express integrins to varying degrees. After long-term culturing, ARPE19 cells resemble mature RPE cells, and increase integrin expression. We hence argue that it is important to test the properties of these cells prior to transplantation to avoid failure of adhesion and to facilitate correct function.

\section{Keywords}

retina, age-related macular degeneration, retinal pigment epithelium, integrin, ARPE19, extracellular matrix, immunostaining 


\section{Introduction}

The retinal pigment epithelium (RPE) is located behind the neural retina, forming a barrier between the photoreceptor cells and the blood vessels of the choroid. RPE cells are critical for the development and integrity of the outer retina. They transport nutrients from blood vessels to photoreceptors and phagocytose shed photoreceptor outer segments (POS) as well as playing a role in maintaining the blood-retina barrier [1-3]. Integrins are crucial for the proper functioning of the RPE cells. The adhesion of the RPE monolayer to its normal substrate, Bruch's membrane, is mediated via integrins [4,5]. Additionally, $\alpha \mathrm{V} \beta 5$ integrin is essential for POS binding and subsequent phagocytosis through CD36 and the protooncogene tyrosine-protein kinase MER (MERTK) [3,6-9]. Integrins are transmembrane signaling molecules that are formed through the hetero-dimerization of an $\alpha$ and a $\beta$ subunit $[10,11]$. They are important adhesion molecules, binding to a variety of extracellular matrix (ECM) cues as well as cell surface markers and growth factors [12,13].

During aging and in disease state, the ECM composition of Bruch's membrane changes and, together with accumulation of toxic waste due to a decline in the efficiency of phagocytosis and subsequent recycling and degradation may lead to the dysfunction and ultimate death of RPE cells [14-17].

RPE cell transplantation has been employed as a treatment to replace damaged or lost RPE cells in retinal diseases such as Stargardt disease, age-related macular degeneration (AMD) and retinitis pigmentosa. However, attempts to transplant new RPE cells into diseased eyes of human AMD patients have been proven challenging [18-25]. Even though the transplantation resulted in improved vision in some cases, most of the grafts did not attach and survive in the pathological microenvironment due to immune rejection and failed adhesion [19,26-32]. Early results from the recent clinical trials involving stem cell-derived RPE cells are promising as no signs of adverse effects such as tumorigenesis were described [33-35]. Despite the reported improved vision in patients it is still unknown whether the transplanted cells adhere properly to the pathological Bruch's membrane and whether they form a polarized monolayer in vivo [36].

Several different types of RPE cells have been used to study the behavior of the cells ex vivo prior to transplantation or to model diseases. Cell lines [37-40], including the widely used human RPE cell line ARPE-19 [41], and primary RPE cells such as fetal [42,43] and adult human cells [44] as well as stem cell-derived RPE cells [45-48] were used in transplantation experiments in animal models with varying degrees of success [49].

One of the problems with the ex vivo expansion of RPE cells prior to transplantation is dedifferentiation of the cells. For example, ARPE-19 cells express RPE-specific genes to a reduced degree [50] but upregulate neuronal markers [51]. In addition, the dissociation of RPE 
cells prior to transplantation can lead to the dedifferentiation of the cells and they then have to redifferentiate in vivo $[46,47,52-54]$.

Here, we assessed the integrin expression in rat RPE cells in situ and in culture as well as in differentiated and undifferentiated ARPE-19 cells by immunocytochemistry to get a better understanding of the abilities of the different variety of RPE cells to attach to Bruch's membrane after transplantation.

\section{Material and Methods}

\subsection{Cell culture}

\subsubsection{Primary adult rat RPE cells}

All animal work was carried out in accordance with the UK Animals (Scientific Procedures) Act 139 (1986) and within UK Home Office regulations. Adult Sprague Dawley (SD) rats (Charles River; 250-300 g, 8-10 weeks) were used for tissue. Primary adult rat RPE cell cultures were prepared as described previously [55]. In brief, whole eyes were incubated in papain (Worthington; $20 \mathrm{U} / \mathrm{ml}$ ) for 50 minutes at $37^{\circ} \mathrm{C}$. Afterwards, the retina with attached RPE cells was dissected out, and the rest of the eye was discarded. After a second digestion of the retina-RPE complex in papain $(20 \mathrm{U} / \mathrm{ml})$ for ten minutes at $37^{\circ} \mathrm{C}$ the RPE cells were carefully peeled off and plated on Matrigel (BD Biosciences; 1:80 in DMEM)-coated glass coverslips in 'Miller' medium [DMEM supplemented with 5 or $20 \%$ fetal bovine serum ( $\mathrm{v} / \mathrm{v}), \mathrm{N} 1$ medium supplement, MEM non-essential amino acids, $2 \mathrm{mM}$ GlutaMAX, $250 \mathrm{mg} / \mathrm{ml}$ taurine, $20 \mathrm{ng} / \mathrm{ml}$ hydrocortisone, 13 $\mathrm{ng} / \mathrm{ml}$ triiodothyronine and $1 \%$ penicillin/streptomycin $(\mathrm{v} / \mathrm{v}) ; 56,57]$.

\subsubsection{ARPE-19 cells}

ARPE-19 cells [41] were purchased from ATCC. Cells were plated on cell culture-treated plastic in $\mathrm{DMEM}^{+}$[DMEM, high glucose, pyruvate, supplemented with $1 \%$ fetal calf serum $(\mathrm{v} / \mathrm{v})$ and $1 \%$ penicillin/streptomycin (v/v); 58]. Cells were fed twice a week and split when confluent. When kept in culture without splitting cells became pigmented after five months.

\subsection{Immunochemistry}

\subsubsection{Immunocytochemistry}

ARPE-19 cells were briefly trypsinized and plated in small number on Matrigel-coated glass coverslips. We used undifferentiated (cultured for two weeks) and differentiated (cultured for 
five months) ARPE-19 cells as well as two week old primary rat RPE cell cultures for the immunostaining.

Cells were fixed with either $2 \%$ (integrin staining) or $4 \%$ (RPE marker staining) paraformaldehyde (PFA) for $15 \mathrm{~min}$ at room temperature and washed three times with PBS. Subsequently, the cells were permeabilized and blocked using PBS supplemented with $0.3 \%$ Triton-X 100 (PBST) and 5\% milk (integrin staining) or 10\% donkey serum (RPE marker staining) for one hour. Afterwards, cells were incubated in primary antibody solution (antibody diluted in $5 \%$ milk or $5 \%$ donkey serum in PBST (Table 1)) over night ( 14 to 16 hours) at $4^{\circ} \mathrm{C}$. The next day, cells were incubated in secondary antibody solution (antibody diluted in PBST (Table 2)) for one hour. Afterwards, the cells were washed and mounted onto slides for imaging.

\subsubsection{Immunohistochemistry}

Adult SD rats (Charles River; 250-300 g, 8-10 weeks) were perfused transcardially with 4\% PFA in 0.1 M PBS, pH 7.2-7.4, after overdose of general anesthetic (Euthatal $(200 \mathrm{mg} / \mathrm{ml}$ solution, Rhône-Mérieux)). Afterwards, eyes were dissected out and excess connective tissue and muscle attachments were removed. The lens and anterior chamber were carefully removed together with the vitreous humor. Care has to be taken to not destroy or detach the retina. The eyes were immediately post-fixed in $4 \%$ PFA overnight at $4^{\circ} \mathrm{C}$. The tissue was transferred into $30 \%$ sucrose (Sigma) in PBS, for cryoprotection. The eyes were then frozen in O.C.T. (Raymond Lamb) and sectioned using a cryostat (Cryostat Leica CM 3050S). Fourteen $\mu \mathrm{m}$ thick sections were mounted on glass slides (Superfrost ${ }^{\circledR}$ Plus, VWR) and stored at $-20^{\circ} \mathrm{C}$. For immunostaining, cryosections on glass slides were air-dried for one hour and then washed three times for $5 \mathrm{~min}$ with PBS. Afterwards, the sections were stained following the same protocol as the cells (see above).

\subsection{Image analysis}

Cell cultures were first immunostained and imaged for the proteins of interest. When expression levels were compared between conditions the same acquisition settings were used for all images. Then, at least 30 cells were chosen at random for each condition to analyze the fluorescence intensity of the whole cell using the Fiji software [59]. All data were analyzed using unpaired t-tests with Welch's correction using GraphPad Prism software. Each experiment was repeated three times. The results are presented as mean + standard deviation. Significance values were represented as: ${ }^{* *}=P<0.01,{ }^{* \star *}=P<0.001$.

\section{Results}


Integrins are ubiquitously expressed throughout the retina, mediating a variety of functions. For instance, on RPE cells, they mediate the interaction with Bruch's membrane and the phagocytosis of shed POS $[1,3,5]$. In this study we analyzed and compared the expression of integrin subunits in different RPE cells using immunostaining. We assessed the integrin expression in situ using rat eye cryosections, in primary rat RPE cells [55], and in the spontaneously immortalized human RPE cell line ARPE-19 [41] using differentiated and undifferentiated cells [58].

\subsection{Integrin expression in RPE cells in situ}

As a first step, we assessed the expression of integrins in situ. To this end, we used cryosections of adult SD rat eyes and performed immunostaining targeting integrin subunits. In addition to the integrins already assessed in our previous studies, $\alpha 1, \alpha 3, \alpha 5$ and $\alpha \mathrm{V}$ as well as $\beta 1$ and $\beta 3$ [60], we expanded the pallet of integrins evaluated by $\alpha 6$, $\alpha 8$, and $\beta 4$. As discussed previously [60], the $\alpha 1$ integrin subunit was expressed by a variety of cells within the retina. Expression of $\alpha 1$ was visible in the RPE cells (visualized by red fluorescence [65 kDa RPE specific protein (RPE65); 61,62]), the retinal ganglion cells (RGCs), cell bodies and processes throughout the length of the retina (Figure 1, $\alpha 1$ ). The $\alpha 3$ integrin subunit was visible in the RPE cells and cell processes in the inner plexiform layer (IPL) and the ganglion cell layer (GCL) (Figure 1, a3). a5 integrins were expressed in the choroid, RPE cells, and throughout the whole length of the retina (Figure 1, a5). No expression of the a6 integrin subunit was detectable in the retina. However, this integrin subunit was visible within the sclera and the choroid and to some extent in RPE cells (Figure 1, a6). The a8 integrin subunit was clearly detectable in the inner nuclear layer (INL) and the RGC layer with some immunoreactivity visible in the RPE cell layer (Figure 1, a8). RPE cells, cells in the INL and $I P L$, and RGCs expressed the $\alpha \mathrm{V}$ integrin subunit (Figure $1, \alpha \mathrm{V}$ ). $\beta 1$ integrin subunit expression was obvious in the RPE layer, the INL and the RGC layer (Figure 1, $\beta 1$ ). Immunoreactivity of the $\beta 3$ integrin subunit was visible in the RPE cells and cell processes in the IPL and GCL (Figure 1, $\beta 3$ ). The $\beta 4$ integrin subunit was found in the RPE cells, the INL and the RGC layer (Figure 1, $\beta 4$ ). In summary, RPE cells in situ expressed all the integrin subunits tested. 

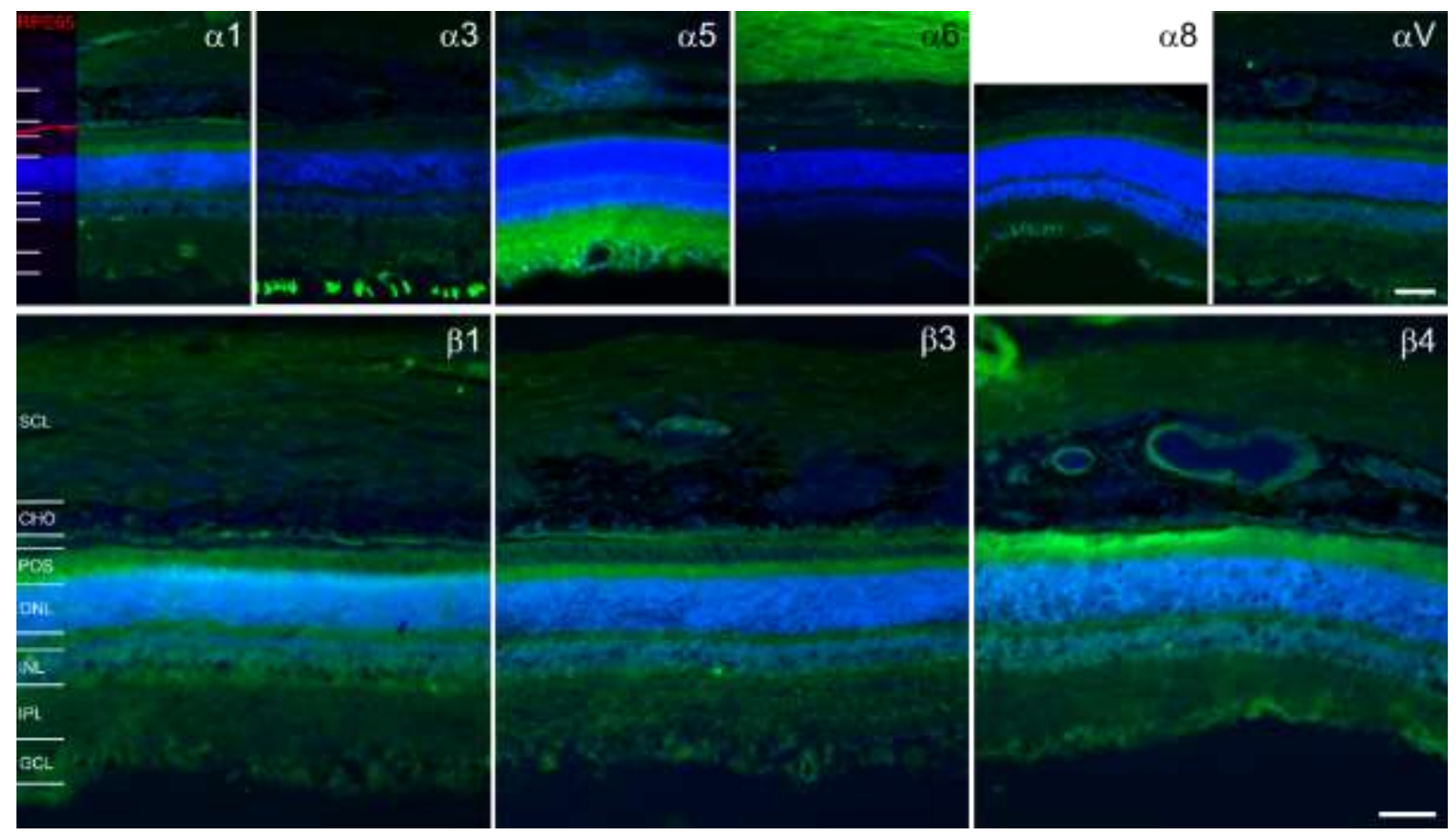

Figure 1: Expression of integrin subunits in the rat retina.

(a1) Immunostaining for the a1 integrin subunit (green) revealed its presence in the RPE cells and the RGCs as well as cell processes throughout the length of the retina. RPE cells are labeled with RPE65 (red). (a3) The $\alpha 3$ integrin subunit (green) was expressed in the RPE cells, cell processes in the IPL and in RGC cell bodies. ( $\mathbf{\alpha} 5)$ Expression of the a5 integrin subunit (green) was illuminated in the choroid, the RPE cells, the INL and IPL and the RGC layer. (a6) The $\alpha 6$ integrin subunit (green) was expressed by the RPE cells, and cells in the choroid and the sclera. (a8) Immunostaining showed expression of the a8 integrin subunit (green) in the INL and the RGC layer. Some immunoreactivity was also detectable in the RPE cell layer. $(\boldsymbol{\alpha V})$ The $\alpha \mathrm{V}$ integrin subunit (green) was expressed by the RPE cells, cells in the INL and IPL, and the RGCs. ( $\beta 1$ ) The $\beta 1$ integrin subunit (green) was visualized in the RPE cells, the INL and the RGC layer. ( $\beta 3$ ) The $\beta 3$ integrin subunit (green) was expressed by the RPE cells and cell processes in the IPL. ( $\beta 4)$ RPE cells, cells in the INL and the RGC layer expressed the $\beta 4$ integrin subunit (green). Cell nuclei are labelled with DAPI (blue) throughout. SCL = sclera, $\mathrm{CHO}=$ choroid, POS $=$ photoreceptor outer segments, $\mathrm{ONL}=$ outer nuclear layer, $\mathrm{INL}=$ inner nuclear layer, $\mathrm{IPL}=$ inner plexiform layer, $\mathrm{GCL}=$ ganglion cell layer. Scale bars $=50 \mu \mathrm{m}$.

\subsection{Integrin expression in primary adult rat RPE cells}

Next, we cultured adult rat RPE cells as described previously [55] and assessed their integrin expression. We used SD rat-derived cells to avoid autofluorescence from the pigments as these rats are albino. We cultured the cells for two weeks before fixation and immunostaining. The RPE cells formed a cobble-stone like monolayer in culture, a hallmark for RPE cells (Figure 2, A), and expressed the RPE cell markers cytokeratin 18 (Figure 2, B) and zonula occludens-1 (ZO-1) (Figure 2, C) confirming their lineage [62-64]. 

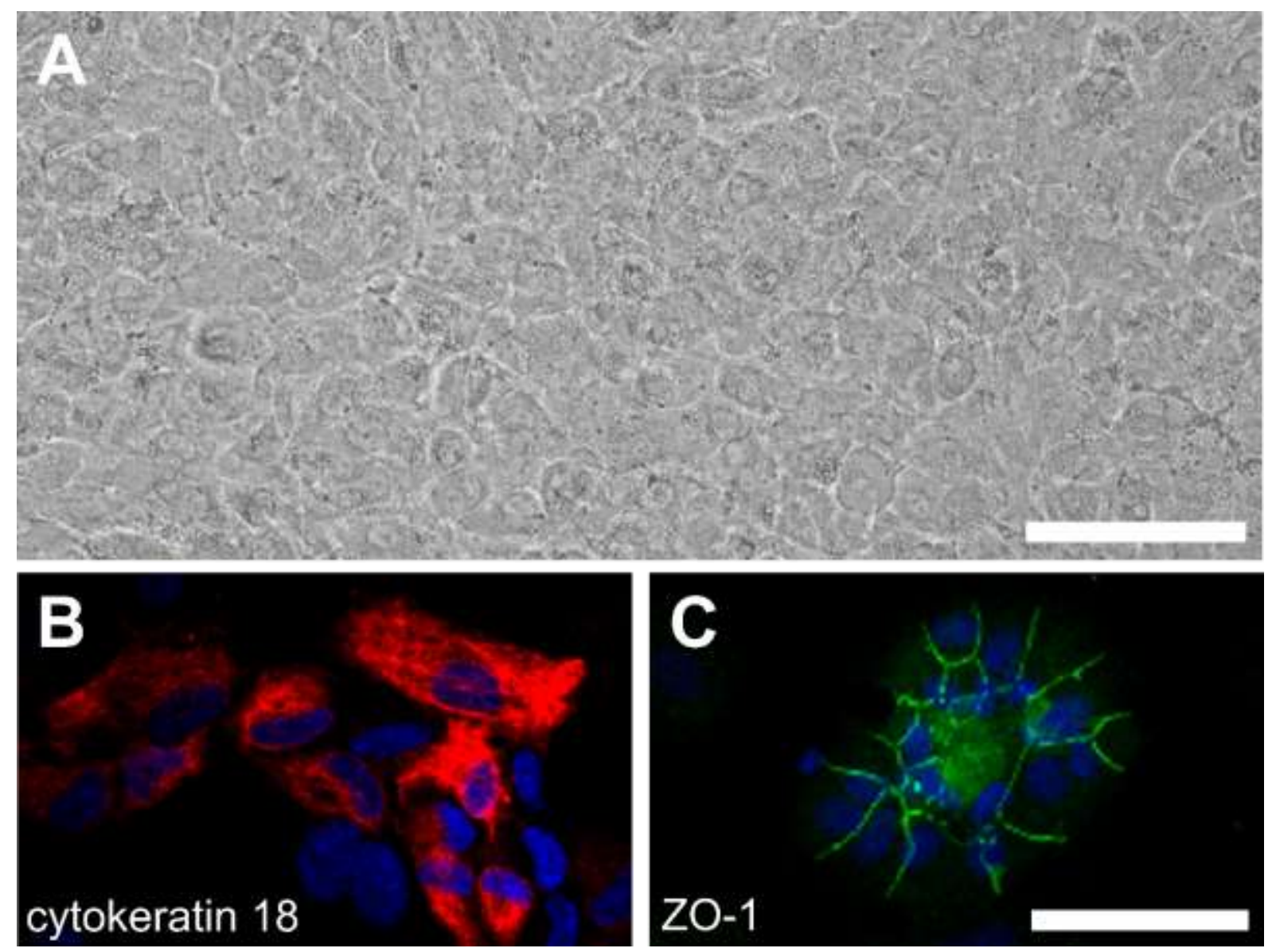

Figure 2: Cultured primary adult rat RPE cells.

(A) SD rat-derived RPE cells formed a non-pigmented monolayer in culture. (B and C) The cells expressed the RPE cell markers cytokeratin 18 (red) and ZO-1 (green). Cell nuclei were labelled with DAPI (blue). Scale bar = $100 \mu \mathrm{m}$.

We performed immunostaining on SD rat-derived RPE cells to visualize integrin subunits expressed by the cells. The immunostaining revealed varying degrees of expression of the $\alpha 1, \alpha 2, \alpha 3, \alpha 4, \alpha 5$ and $\alpha \mathrm{V}, \beta 1, \beta 4$ and $\beta 5$ integrin subunits as well as of $\alpha \mathrm{V} \beta 3$ and $\alpha \mathrm{V} \beta 5$ integrins (Figure 3). Especially the immunostaining against the $\alpha 8$ and $\beta 3$ integrin subunit showed a lot of background signal. On the other hand, the $\alpha 3, \alpha 5$ and $\alpha \mathrm{V}$ as well as the $\beta 1$ and $\beta 4$ integrin subunits were localized to large focal adhesions (intense staining around edges of the cells, marked by arrows) in the cultured RPE cells (Figure 3), confirming their role in the adhesion of the cells. 
bioRxiv preprint doi: https://doi.org/10.1101/2020.06.26.133553; this version posted June 27, 2020. The copyright holder for this preprint (which was not certified by peer review) is the author/funder, who has granted bioRxiv a license to display the preprint in perpetuity. It is made available under aCC-BY-NC-ND 4.0 International license.

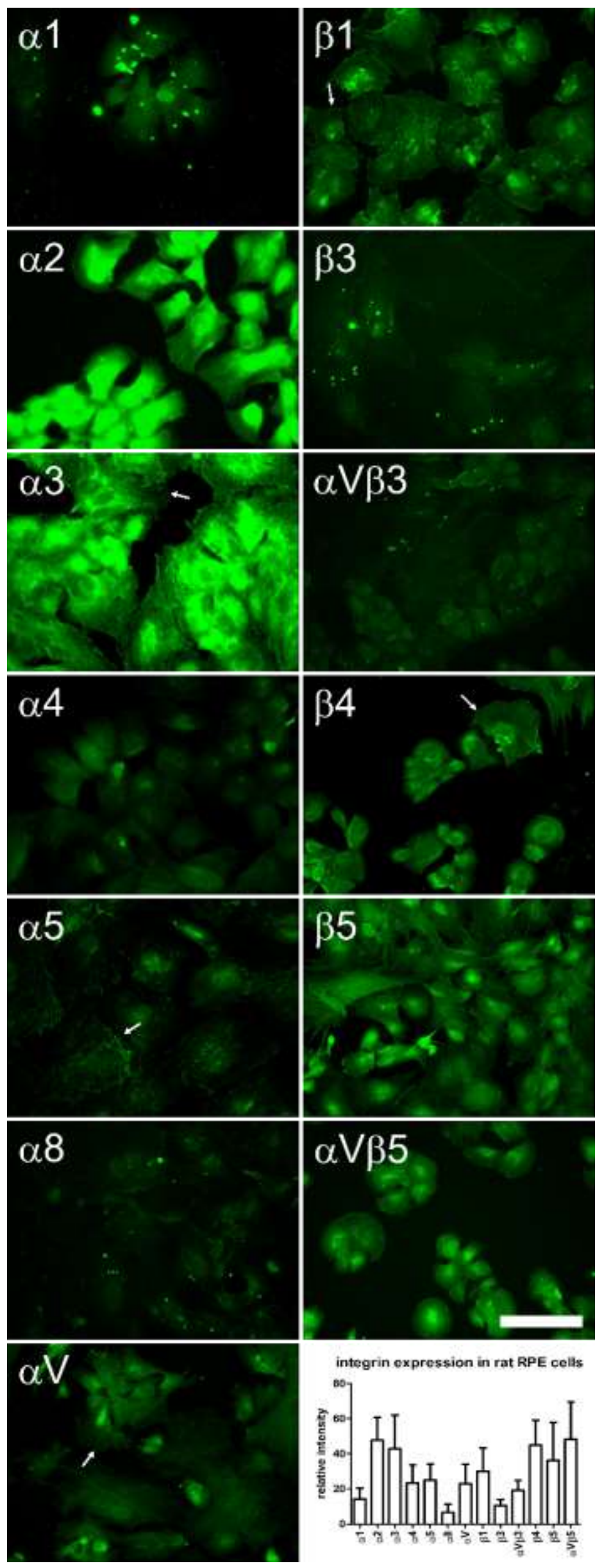


bioRxiv preprint doi: https:/doi.org/10.1101/2020.06.26.133553: this version posted June 27, 2020. The copyright holder for this preprint (which was not certified by peer review) is the author/funder, who has granted bioRxiv a license to display the preprint in perpetuity. It is made available under aCC-BY-NC-ND 4.0 International license.

Figure 3: Integrin expression in cultured primary rat RPE cells.

The cultured RPE cells expressed $\alpha 1, \alpha 2, \alpha 3, \alpha 4, \alpha 5$ and $\alpha \mathrm{V}, \beta 1, \beta 4$ and $\beta 5$ integrin subunits as well as $\alpha \mathrm{V} \beta 3$ and $\alpha \vee \beta 5$ integrins. The signals for the $\alpha 8$ and $\beta 3$ integrin subunits were very weak and might be due to unspecific binding of the antibodies. However, the labelling of the $\alpha \mathrm{V} \beta 3$ integrin appeared specific as it was targeted to the plasma membrane. The $\alpha 3, \alpha 5$ and $\alpha \mathrm{V}$ as well as the $\beta 1$ and $\beta 4$ integrin subunits were found in large focal adhesions (arrows). Scale bar $=100 \mu \mathrm{m}$.

\subsection{Integrin expression in ARPE-19 cells}

After establishing the integrin expression in primary rat RPE cells we used immunostaining to visualize the presence of integrins in the widely used human RPE model cell line ARPE-19 [41]. The cells resembled epithelial cells in culture $24 \mathrm{~h}$ after plating (Figure 4, A), and they formed a monolayer after several days in culture (Figure 4, B). Culturing ARPE-19 cells in $\mathrm{DMEM}^{+}[58]$ enabled the cells to redifferentiate and to form a tight monolayer after several months in culture (Figure 4, C). The cells in $\mathrm{DMEM}^{+}$started to get pigmented after $\sim$ five months and continued to do so until the whole monolayer was pigmented after seven months (Figure 4, D).

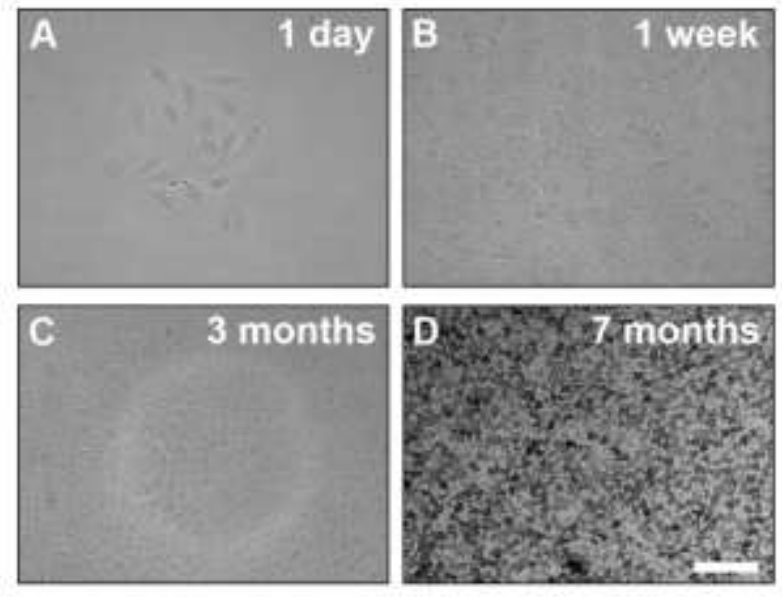

Figure 4: Culture of ARPE-19 cells.

(A) ARPE-19 cells resembled epithelial cells in culture $24 \mathrm{~h}$ after plating. (B) The cells formed a disorganized monolayer after one week in culture. (C) ARPE-19 cells cultured in DMEM+ [58] re-differentiated and formed a tight monolayer after several months. (D) The monolayer started to get pigmented after five months in culture, and all cells were pigmented after $\sim$ seven months. Scale bar $=100 \mu \mathrm{m}$.

Next, we used immunocytochemistry to assess the expression of RPE-specific markers in ARPE-19 cells cultured in DMEM+ (Figure 5). We used undifferentiated (ARPE-19 cells cultured for two weeks) and differentiated ARPE-19 cells that were cultured for five months. Low levels of bestrophin [BEST; 65,66], cellular retinaldehyde binding protein [CRALBP; 61] and RPE65 were visible in the undifferentiated ARPE-19 cells (Figure 5). However, the cells expressed cytokeratin 18 and microphthalmia-associated transcription factor [MiTF; 67,68] 
(Figure 5). Moreover, immunostaining for the $\mathrm{Na}^{+} / \mathrm{K}^{+}-\mathrm{ATP}$ ase [69] revealed strong immunoreactivity in the perinuclear region of the undifferentiated ARPE-19 cells (Figure 5). The tight junction marker ZO-1 was localized to the cell-cell-contacts but immunostaining exposed a non-organized staining pattern (Figure 5). On the other hand, the differentiated ARPE-19 cells expressed significantly higher levels (unpaired $t$-tests with Welch's correction: ${ }^{* * *}=P<0.001$ ) of all the RPE-specific markers tested (Figure 5), resembling native RPE cells [55]. 
bioRxiv preprint doi: https://doi.org/10.1101/2020.06.26.133553; this version posted June 27, 2020. The copyright holder for this preprint (which was not certified by peer review) is the author/funder, who has granted bioRxiv a license to display the preprint in perpetuity. It is made available under aCC-BY-NC-ND 4.0 International license.

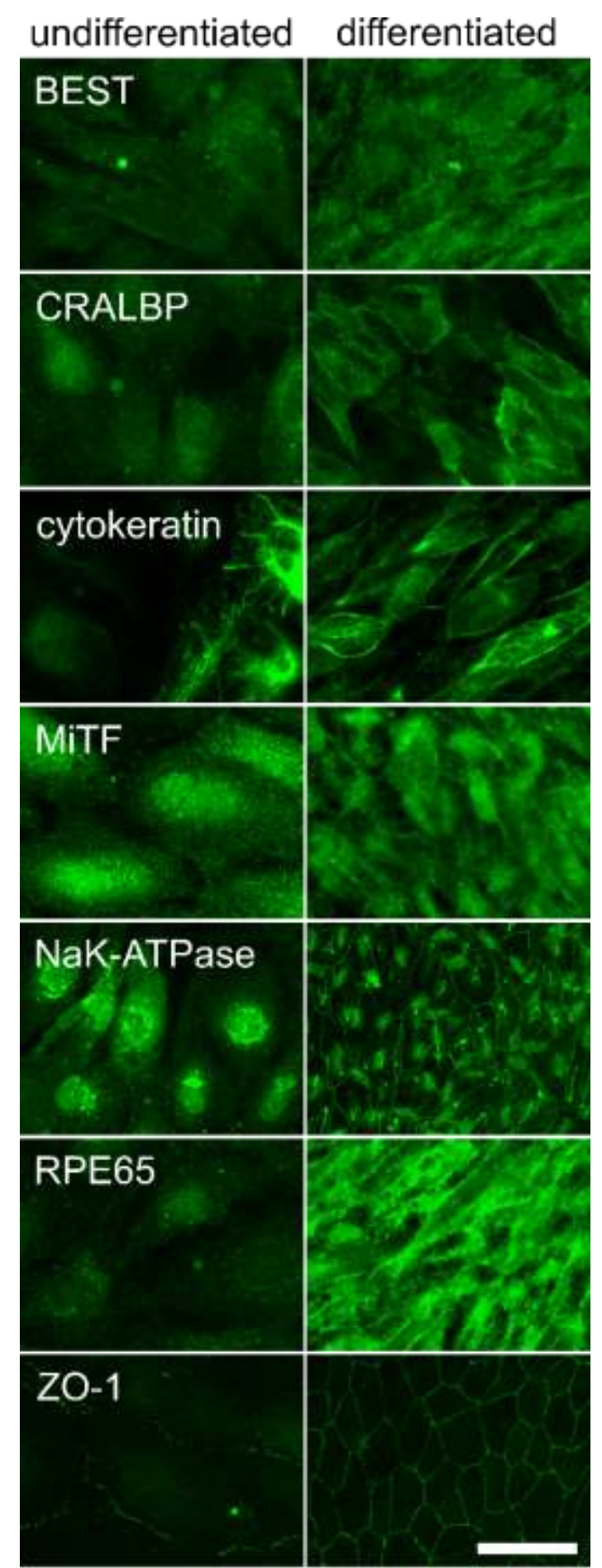

RPE marker expression

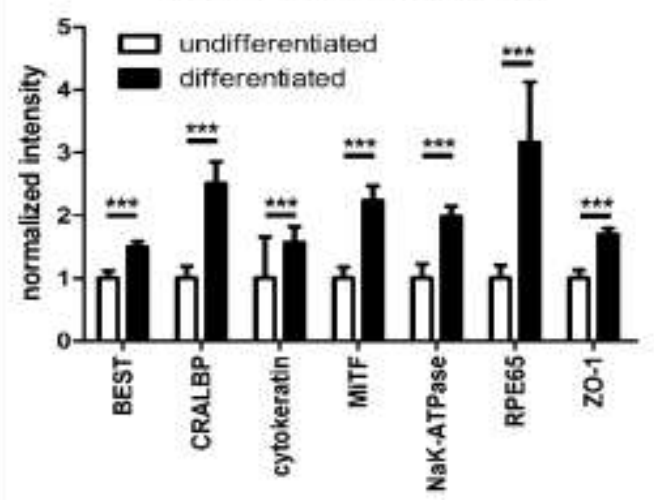


Figure 5: Expression of RPE-specific markers in ARPE-19 cells.

Undifferentiated (cells cultured for two weeks) and differentiated ARPE-19 (cells cultured for five months) were used for immunostaining to assess the expression of RPE-specific markers. The undifferentiated ARPE-19 cells expressed low levels of BEST, CRALBP and RPE65. However, they expressed cytokeratin 18, MiTF, the $\mathrm{Na}^{+} / \mathrm{K}^{+}-$ ATPase and the tight junction marker ZO-1. The differentiated ARPE-19 cells expressed significantly higher levels of all the RPE-specific markers tested (unpaired $t$-tests with Welch's correction: ${ }^{* * *}=P<0.001$ ). Scale bar $=50 \mu \mathrm{m}$.

After confirming the expression of RPE-specific markers in ARPE-19 cells we next assessed the integrin subunit expression in these cells (Figure 6). Again, we used undifferentiated and differentiated cells (see above). Although only low fluorescence signals with high background were detectable for the $\alpha 1, \alpha 5$ and $\alpha 8$ integrin subunits, the undifferentiated ARPE-19 cells expressed the $\alpha 2, \alpha 3, \alpha 4$ and the $\alpha \mathrm{V}$ integrin subunits (Figure 6). In contrast, the differentiated ARPE-19 cells expressed all $\alpha$ integrin subunits tested (Figure 6). Again, only low levels of the a1 integrin subunit were found. However, the differentiated ARPE-19 cells showed an expression of the $\alpha 5$ and the $\alpha 8$ integrin subunits (Figure 6). In addition to $\alpha$ integrin subunits, the undifferentiated ARPE-19 cells expressed the $\beta 1$ integrin subunit and the $\alpha \mathrm{V} \beta 3$ integrin on their surface although the staining for the $\beta 3$ integrin subunit alone was weaker (Figure 6). The undifferentiated ARPE-19 cells expressed the $\beta 4$ integrin subunit which displayed strong staining in the nucleus (Figure 6). Moreover, the cells expressed the $\beta 5$ and the $\alpha \vee \beta 5$ integrin on their cell surface (Figure 6). On the other hand, the differentiated ARPE-19 cells expressed the $\beta 1, \beta 3, \beta 4$ and $\beta 5$ integrin subunits as well as the $\alpha \mathrm{V} \beta 3$ and $\alpha \mathrm{V} \beta 5$ integrins on their surface (Figure 6). With the exception of the $\beta 3$ integrin subunit, the differentiated ARPE-19 cells expressed significantly higher levels (unpaired $t$-tests with Welch's correction: ${ }^{*}=P<0.01$ and $^{* * *}=P<0.001$ ) of all integrins assessed (Figure 6). 
bioRxiv preprint doi: https://doi.org/10.1101/2020.06.26.133553; this version posted June 27, 2020. The copyright holder for this preprint (which was not certified by peer review) is the author/funder, who has granted bioRxiv a license to display the preprint in perpetuity. It is made available under aCC-BY-NC-ND 4.0 International license.

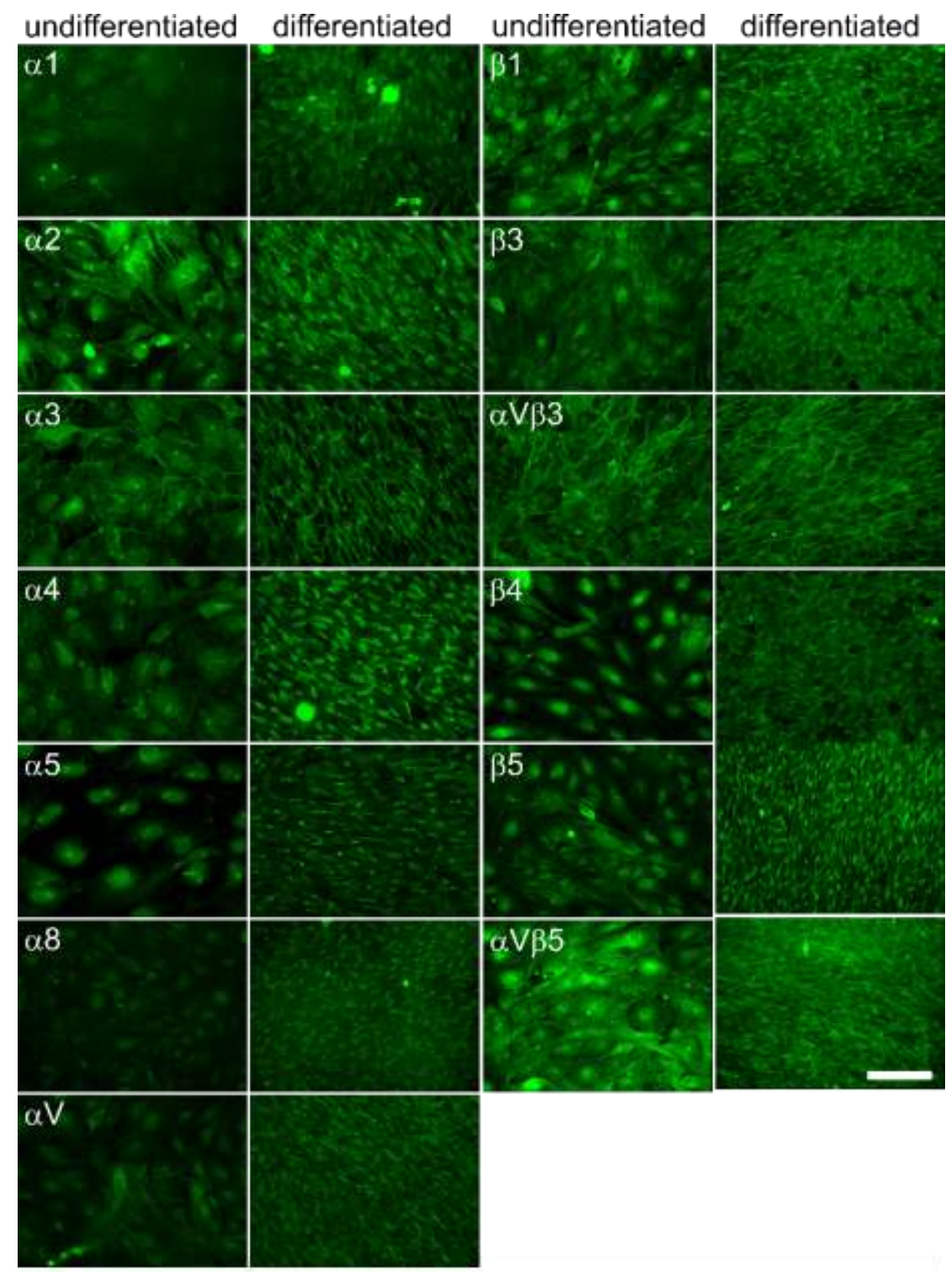

Integrin expression in ARPE-19 cells

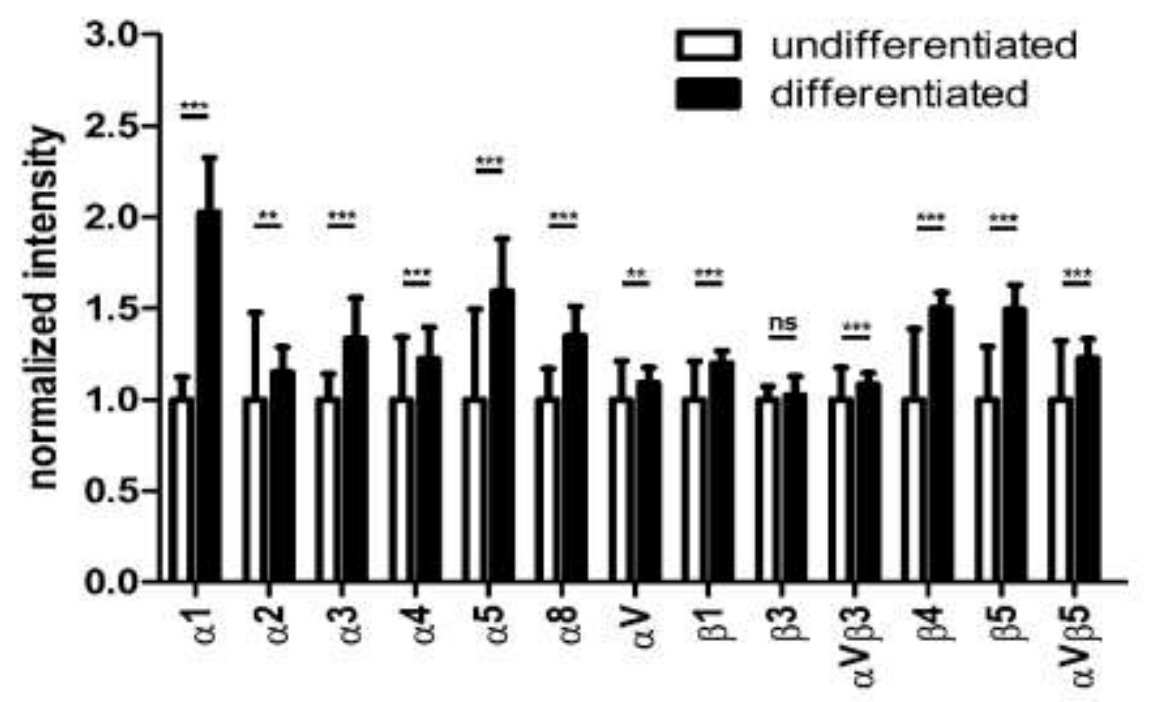


Figure 6: Expression of integrin subunits in ARPE-19 cells.

We performed immunostaining on undifferentiated and differentiated ARPE-19 cells to assess the presence of integrin subunits. Undifferentiated ARPE-19 cells expressed the $\alpha 1, \alpha 2, \alpha 3, \alpha 4, \alpha 5$, $\alpha 8$ and $\alpha \mathrm{V}$ integrin subunits. The immunoreactivity for the $\alpha 1$, the $\alpha 5$ and the $\alpha 8$ integrin subunit was very faint. Also the differentiated ARPE19 cells expressed low levels of the $\alpha 1$ integrin subunit. However, they expressed the $\alpha 2, \alpha 3$, $\alpha 4$ and $\alpha \mathrm{V}$ integrin subunits as well as $\alpha 5$ and $\alpha 8$ integrin subunits. The $\alpha 5$ subunit displayed a staining pattern different to the other integrin subunits tested and revealed long stretches of the protein on the cell surface. Moreover, the $\alpha 8$ integrin subunit immunoreactivity was mostly visible in the nucleus. The undifferentiated ARPE-19 cells expressed the $\beta 1$, $\beta 3, \beta 4$ and $\beta 5$ integrin subunits as well as the $\alpha \mathrm{V} \beta 3$ and $\alpha \mathrm{V} \beta 5$ integrins. However, the fluorescence signal for the $\beta 3$ integrin subunit was very weak, and the $\beta 4$ integrin subunit was mostly visualized in the cell nuclei. The differentiated ARPE-19 cells expressed the $\beta 1, \beta 3, \beta 4$ and $\beta 5$ integrin subunits as well as the $\alpha \mathrm{V} \beta 3$ and $\alpha \mathrm{V} \beta 5$ integrins on their surface. With the exception of the $\beta 3$ integrin subunit, the differentiated ARPE-19 cells expressed significantly higher levels (unpaired $t$-tests with Welch's correction: ${ }^{* *}=P<0.01$ and ${ }^{* * *}=P<0.001$ ) of all integrins assessed. Scale bar $=100 \mu \mathrm{m}$.

\section{Discussion}

In this study we investigated the expression of integrin subunits in the retina in situ, in primary adult rat RPE cells and in the human RPE cell line ARPE-19 using immunostaining. Moreover, we evaluated the impact of long-term culturing of ARPE-19 cells on the expression of RPE markers as well as integrin subunits.

The immunostaining results of the integrin expression in the retina are in line with previously published data. The a1 integrin subunit has been located in RGCs [70] and the RPE layer $[4,60,71]$. Also the $\alpha 3$ integrin subunit has been shown to be expressed throughout the retina [60]. Main points of expression are the RPE cells [4,71,72] and Müller glia, synaptic layers as well as amacrine and some cone cells [73]. Therefore, the staining in the RGC layer in Figure 1 might reflect the Müller cell endfeet as well as displaced amacrine cells. It was demonstrated that the $\alpha 5$ integrin subunit is expressed by the RPE cells [4,74-76]. Furthermore, $\alpha 5$ integrin subunit staining has been demonstrated in the outer plexiform layer (OPL), outer nuclear layer $(\mathrm{ONL})$ and INL, as well as in the RGC layer similar to our results $[60,73]$. The $\alpha 6$ integrin subunit has only been identified in the developing neural retina [72,77]. Additionally, some studies showed its expression in RPE cells similar to our findings [71,78]. Fitting with our results, expression of the $\alpha 8$ integrin subunit has been localized to RGC axons and cells in the INL $[79,80]$. In addition, we saw some expression in the ONL as well as the RPE cell layer which has not been reported yet. The $\alpha \mathrm{V}$ integrin subunit has also been studied intensively in the retina [60]. It is expressed in RPE cells $[4,6,74,81,82]$ and by cells in the INL and ONL, OPL, the POS layer as well as in RGCs [82], which matches our findings.

Besides the $\alpha$ integrin subunits we localized three $\beta$ integrin subunits in the rat retina. $\beta 1$ integrin subunit expression has been demonstrated in RPE cells $[4,75,83]$, RGCs and other neurons in the retina as well as Müller cells $[60,80,84]$ which suggests a similar staining pattern to our results. Also the $\beta 3$ integrin subunit has been visualized in the retina $[60,84]$ with a weak 
bioRxiv preprint doi: https:/doi.org/10.1101/2020.06.26.133553; this version posted June 27, 2020. The copyright holder for this preprint (which was not certified by peer review) is the author/funder, who has granted bioRxiv a license to display the preprint in perpetuity. It is made available under aCC-BY-NC-ND 4.0 International license.

staining in the nerve fiber layer [72]. In addition, the $\beta 3$ integrin subunit is expressed by RPE cells $[81,85,86]$ as seen in our immunostaining experiments. The $\beta 4$ integrin subunit is expressed by the RPE cells and forms a heterodimer with the $\alpha 6$ integrin subunit. The $\alpha 6 \beta 4$ integrin links laminin in the ECM to the keratin intermediate filaments of the cytoskeleton $[4,87]$. Surprisingly, our staining showed a distribution of the $\beta 4$ integrin subunit throughout the retina, with strong immunoreactivity in cell bodies in the INL and the RGC layer. However, the $\beta 4$ integrin subunit has only been shown to dimerize with the a6 integrin subunit $[11,13]$. Nevertheless, our a6 integrin subunit staining did not show any immunoreactivity in the retina. Potentially, this might be due to the use of an antibody raised in rat and used on rat tissue. Hence, either one of the immunostaining reactions yielded unspecific results or the $\beta 4$ integrin subunit is able to form a heterodimer with an integrin subunit other than $\alpha 6$. Some published data suggest the existence of an $\alpha \mathrm{V} \beta 4$ integrin $[88,89]$. However, the staining for the $\alpha \mathrm{V}$ integrin subunit alone did not show a distinct staining pattern in the cell bodies in the INL as seen in the staining for the $\beta 4$ integrin subunit. Thus, the $\beta 4$ integrin subunit might interact with a yet unknown dimerization partner.

In this study, we used immunostaining to assess the presence of integrin subunits in cultured primary adult rat RPE cells isolated using papain. The cells expressed several $\alpha$ ( $\alpha 1-5, \alpha 8$ and $\alpha \mathrm{V}$ ) as well as $\beta(\beta 1, \beta 3-\beta 5)$ integrin subunits which confirmed previous studies (see above). However, we did not perform gene expression analyses. Several mouse expression profiles have been published already, confirming the integrin expression pattern [90-92].

The human RPE cell line ARPE-19 has been used as a model for RPE cells for several decades $[29,37,40,41,86,93]$. However, the cells are non-pigmented, and it is difficult to detect essential RPE markers such as RPE65 in the cells [41,46,58,94-97]. Using immunostaining we were only able to clearly visualize cytokeratin $18, \mathrm{MiTF}, \mathrm{Na}^{+} \mathrm{K}^{+}-\mathrm{ATP}$ ase and ZO-1 in undifferentiated ARPE-19 cells. This is in agreement with other studies [58]. However, upon differentiation using long-term culturing in $\mathrm{DMEM}^{+}$(culturing for at least five months) the cells became pigmented and started to express RPE markers BEST, CRALBP and RPE65 (Figure 5) [58]. Ahmado and colleagues reported the pigmentation of ARPE-19 cells in DMEM+ after three months [58]. Low serum and the presence of pyruvate induce the pigmentation of the ARPE-19 cells. Additionally, the expression levels for CRALBP, MERTK and RPE65 are highest under pyruvate conditions [58]. It is therefore important to indicate in which state of differentiation the ARPE-19 cells are as each state shows distinct phenotypes and expresses a different battery of genes. 
Using immunostaining we identified several $\alpha$ and $\beta$ integrin subunits in ARPE-19 cells. One has to bear in mind however that the culture medium [76], the culture substrate [98] as well as the passage number [99] influence gene expression. Proulx et al. showed that the expression of the $a 5$ integrin subunit declines when cells reach post-confluency levels [75,76]. Similarly, in our immunostaining study the staining for the a5 integrin subunit changed when comparing undifferentiated and differentiated ARPE-19 cells. Even though the overall staining intensity increased, strong immunoreactivity at cell-cell borders that appeared as 'worm-like' structures became visible. However, with the exception of the $\beta 3$ integrin subunit, the expression of the other integrin subunits tested increased during the transition of the ARPE-19 to a pigmented and more native phenotype. This was especially visible for the $\alpha 1$, the $\beta 4$ and the $\beta 5$ integrin subunits as well as for the $\alpha \mathrm{V} \beta 5$ integrin. The $\alpha 1$ and the $\beta 4$ integrin subunits are involved in the adhesion of the RPE cells to laminin [87,100], an ECM molecule that is produced by RPE cells [55,78]. Additionally, as mentioned, the $\alpha \mathrm{V} \beta 5$ integrin is essential for RPE cell function, i.e. binding of POS and subsequent phagocytosis through CD36 and MERTK [3,6-9]. Our results also fit with gene expression profiles that have been published for ARPE19 cells [101], fetal and adult human RPE cells [102,103] as well as stem cell-derived RPE cells [104,105].

All RPE cells tested expressed integrins which enable them to interact with normal Bruch's membrane. However, as mentioned above, the composition of the Bruch's membrane changes during aging and in disease making it more anti-adhesive [14-17]. Moreover, the removal of choroidal new vessels in the treatment of AMD leads to the exposure of deeper layers of Bruch's membrane [106-109] that do not favor the attachment of RPE cells $[26,27,29,30,110]$. In addition, in wet AMD an upregulation of the inhibitory glycoprotein tenascin-C (TN-C) occurs on Bruch's membrane [86,111,112] in addition to changes in proteoglycan composition, which might also render the membrane less adhesive [113]. It has been shown that RPE cells express at least one receptor that normally binds to TN-C, $\alpha \mathrm{V} \beta 3$ [86]. $\alpha \mathrm{V} \beta 3$ can be activated through manganese and blocking $\beta 3$ integrins reduces ARPE-19 binding to and migration on TN-C [86]. Surprisingly, we found the expression of the a8 integrin subunit in RPE cells. The $\alpha 8 \beta 1$ integrin is a receptor for TN-C [114,115] and should mediate the adhesion of the RPE cells to TN-C. However, we only detected low levels of this integrin subunit in the RPE cells, similar to gene expression analyses mentioned above. The $\alpha 8 \beta 1$ integrin might be activated together with $\alpha \mathrm{V} \beta 3$ integrin to enable binding to TN-C. Nonetheless, the activation of $\beta 1$ integrins alone did not increase ARPE-19 adhesion to TN-C [86].

Studies showed that $\beta 1$ integrins are the most important receptors for the adhesion and migration of RPE cells and that their blocking leads to a failure of RPE cell attachment and migration [116-118]. In addition, blocking a integrin subunits on RPE cells results in less 
bioRxiv preprint doi: https://doi.org/10.1101/2020.06.26.133553; this version posted June 27, 2020. The copyright holder for this preprint (which was not certified by peer review) is the author/funder, who has granted bioRxiv a license to display the preprint in perpetuity. It is made available under aCC-BY-NC-ND 4.0 International license.

spreading and adhesion of the cells on Bruch's membrane explants and components [71]. Uncultured RPE cells express low levels of integrins on their surface which can impair the reattachment of the cells to Bruch's membrane or other surfaces [4]. As seen in our results, upon culturing however, the levels of surface integrins rise and the cells bind better to Bruch's membrane [4,71]. 


\section{Acknowledgments}

Funding: This work was supported by grants from the Medical Research Council (G10000864) (JH, TH, JK and JF), Christopher and Dana Reeves Foundation (JF), the Wellcome Trust MRC Cambridge Stem Cell Institute and Fight for Sight (KM), Czech Science Foundation GACR 1910365S, project "Center of Reconstructive Neuroscience", CZ.02.1.01/0.0./0.0/15_003/0000419, a Wellcome Trust Principal Fellowship (101896) (JH), the European Union's Horizon 2020 research and innovation program (Marie SkłodowskaCurie grant agreement 798644-AstroMiRimage) $(\mathrm{JH})$ and a research grant from Science Foundation Ireland (SFI, 16/RC/3948) and co-funded under the European Regional Development Fund and by FutureNeuro industry partners $(\mathrm{JH})$.

\section{Author Contributions}

Conceptualization, JH, KM and JF; Methodology, JH, JK; Formal Analysis, JH; Investigation, $\mathrm{JH}$ and $\mathrm{TH}$; Writing - Original Draft Preparation, $\mathrm{JH}$; Writing - Review \& Editing, $\mathrm{JH}, \mathrm{TH}$, JK, KM and JF; Supervision, JK, KM and JF; Funding Acquisition, JF

\section{Conflicts of Interest:}

JF is a paid consultant for Acorda Therapeutics and Novartis. 


\section{References}

1. Strauss, O. The retinal pigment epithelium in visual function. Physiol Rev 2005, 85, 845-881, doi:85/3/845 [pii] 10.1152/physrev.00021.2004.

2. Amram, B.; Cohen-Tayar, Y.; David, A.; Ashery-Padan, R. The retinal pigmented epithelium - from basic developmental biology research to translational approaches. Int J Dev Biol 2017, 61, 225-234, doi:10.1387/ijdb.160393ra.

3. Lakkaraju, A.; Umapathy, A.; Tan, L.X.; Daniele, L.; Philp, N.J.; Boesze-Battaglia, K.; Williams, D.S. The cell biology of the retinal pigment epithelium. Progress in Retinal and Eye Research 2020, 10.1016/j.preteyeres.2020.100846, 100846, doi:10.1016/j.preteyeres.2020.100846.

4. Zarbin, M.A. Analysis of retinal pigment epithelium integrin expression and adhesion to aged submacular human Bruch's membrane. Trans Am Ophthalmol Soc 2003, 101, 499520.

5. Heller, J.P.; Martin, K.R. Enhancing RPE Cell-Based Therapy Outcomes for AMD: The Role of Bruch's Membrane. Translational vision science \& technology 2014, 3, 11, doi:10.1167/tvst.3.3.11.

6. Finnemann, S.C.; Bonilha, V.L.; Marmorstein, A.D.; Rodriguez-Boulan, E. Phagocytosis of rod outer segments by retinal pigment epithelial cells requires alpha(v)beta5 integrin for binding but not for internalization. Proc Natl Acad Sci U S A 1997, 94, $12932-$ 12937.

7. Finnemann, S.C.; Silverstein, R.L. Differential roles of CD36 and alphavbeta5 integrin in photoreceptor phagocytosis by the retinal pigment epithelium. J Exp Med 2001, 194, 12891298.

8. $\quad$ Feng, W.; Yasumura, D.; Matthes, M.T.; LaVail, M.M.; Vollrath, D. Mertk triggers uptake of photoreceptor outer segments during phagocytosis by cultured retinal pigment epithelial cells. J Biol Chem 2002, 277, 17016-17022, doi:10.1074/jbc.M107876200.

9. Nandrot, E.F.; Silva, K.E.; Scelfo, C.; Finnemann, S.C. Retinal pigment epithelial cells use a MerTK-dependent mechanism to limit the phagocytic particle binding activity of alphavbeta5 integrin. Biology of the cell / under the auspices of the European Cell Biology Organization 2012, 104, 326-341, doi:10.1111/boc.201100076.

10. Hynes, R.O. Integrins: bidirectional, allosteric signaling machines. Cell 2002, 110, 673687, doi:S0092867402009716 [pii].

11. Takada, Y.; Ye, X.; Simon, S. The integrins. Genome Biol 2007, 8, 215, doi:gb-20078-5-215 [pii]

10.1186/gb-2007-8-5-215.

12. van der Flier, A.; Sonnenberg, A. Function and interactions of integrins. Cell Tissue Res 2001, 305, 285-298.

13. Humphries, J.D.; Byron, A.; Humphries, M.J. Integrin ligands at a glance. J Cell Sci 2006, 119, 3901-3903, doi:119/19/3901 [pii]

10.1242/jcs.03098.

14. Kinnunen, K.; Petrovski, G.; Moe, M.C.; Berta, A.; Kaarniranta, K. Molecular mechanisms of retinal pigment epithelium damage and development of age-related macular degeneration. Acta ophthalmologica 2012, 90, 299-309, doi:10.1111/j.17553768.2011.02179.x.

15. Dunaief, J.L.; Dentchev, T.; Ying, G.S.; Milam, A.H. The role of apoptosis in agerelated macular degeneration. Arch Ophthalmol 2002, 120, 1435-1442.

16. Del Priore, L.V.; Kuo, Y.H.; Tezel, T.H. Age-related changes in human RPE cell density and apoptosis proportion in situ. Invest Ophthalmol Vis Sci 2002, 43, 3312-3318.

17. Sparrow, J.R.; Hicks, D.; Hamel, C.P. The retinal pigment epithelium in health and disease. Current molecular medicine 2010, 10, 802-823. 
18. Algvere, P.V.; Berglin, L.; Gouras, P.; Sheng, Y. Transplantation of fetal retinal pigment epithelium in age-related macular degeneration with subfoveal neovascularization. Graefes Arch Clin Exp Ophthalmol 1994, 232, 707-716.

19. Algvere, P.V.; Berglin, L.; Gouras, P.; Sheng, Y.; Kopp, E.D. Transplantation of RPE in age-related macular degeneration: observations in disciform lesions and dry RPE atrophy. Graefes Arch Clin Exp Ophthalmol 1997, 235, 149-158.

20. Algvere, P.V.; Gouras, P.; Dafgard Kopp, E. Long-term outcome of RPE allografts in non-immunosuppressed patients with AMD. Eur J Ophthalmol 1999, 9, 217-230.

21. Tezel, T.H.; Del Priore, L.V.; Berger, A.S.; Kaplan, H.J. Adult retinal pigment epithelial transplantation in exudative age-related macular degeneration. Am J Ophthalmol 2007, 143, 584-595, doi:10.1016/j.ajo.2006.12.007.

22. Binder, S.; Krebs, I.; Hilgers, R.D.; Abri, A.; Stolba, U.; Assadoulina, A.; Kellner, L.; Stanzel, B.V.; Jahn, C.; Feichtinger, H. Outcome of transplantation of autologous retinal pigment epithelium in age-related macular degeneration: a prospective trial. Invest Ophthalmol Vis Sci 2004, 45, 4151-4160, doi:45/11/4151 [pii]

10.1167/iovs.04-0118.

23. Binder, S.; Stanzel, B.V.; Krebs, I.; Glittenberg, C. Transplantation of the RPE in AMD. Prog Retin Eye Res 2007, 26, 516-554, doi:S1350-9462(07)00016-X [pii]

10.1016/j.preteyeres.2007.02.002.

24. Binder, S.; Stolba, U.; Krebs, I.; Kellner, L.; Jahn, C.; Feichtinger, H.; Povelka, M.; Frohner, U.; Kruger, A.; Hilgers, R.D., et al. Transplantation of autologous retinal pigment epithelium in eyes with foveal neovascularization resulting from age-related macular degeneration: a pilot study. Am J Ophthalmol 2002, 133, 215-225.

25. Falkner-Radler, C.I.; Krebs, I.; Glittenberg, C.; Povazay, B.; Drexler, W.; Graf, A.; Binder, S. Human retinal pigment epithelium (RPE) transplantation: outcome after autologous RPE-choroid sheet and RPE cell-suspension in a randomised clinical study. Br J Ophthalmol 2011, 95, 370-375, doi:10.1136/bjo.2009.176305.

26. Del Priore, L.V.; Tezel, T.H. Reattachment rate of human retinal pigment epithelium to layers of human Bruch's membrane. Arch Ophthalmol 1998, 116, 335-341.

27. Tezel, T.H.; Del Priore, L.V. Repopulation of different layers of host human Bruch's membrane by retinal pigment epithelial cell grafts. Invest Ophthalmol Vis Sci 1999, 40, 767774.

28. Tezel, T.H.; Del Priore, L.V. Reattachment to a substrate prevents apoptosis of human retinal pigment epithelium. Graefes Arch Clin Exp Ophthalmol 1997, 235, 41-47.

29. Tezel, T.H.; Del Priore, L.V.; Kaplan, H.J. Reengineering of aged Bruch's membrane to enhance retinal pigment epithelium repopulation. Invest Ophthalmol Vis Sci 2004, 45, 33373348.

30. Tezel, T.H.; Kaplan, H.J.; Del Priore, L.V. Fate of human retinal pigment epithelial cells seeded onto layers of human Bruch's membrane. Invest Ophthalmol Vis Sci 1999, 40, 467476.

31. Gullapalli, V.K.; Sugino, I.K.; Van Patten, Y.; Shah, S.; Zarbin, M.A. Retinal pigment epithelium resurfacing of aged submacular human Bruch's membrane. Trans Am Ophthalmol Soc 2004, 102, 123-137; discussion 137-128.

32. Gullapalli, V.K.; Sugino, I.K.; Van Patten, Y.; Shah, S.; Zarbin, M.A. Impaired RPE survival on aged submacular human Bruch's membrane. Exp Eye Res 2005, 80, 235-248, doi:S0014-4835(04)00267-2 [pii]

10.1016/j.exer.2004.09.006.

33. Nommiste, B.; Fynes, K.; Tovell, V.E.; Ramsden, C.; da Cruz, L.; Coffey, P. Stem cellderived retinal pigment epithelium transplantation for treatment of retinal disease. Prog Brain Res 2017, 231, 225-244, doi:10.1016/bs.pbr.2017.03.003.

34. Schwartz, S.D.; Regillo, C.D.; Lam, B.L.; Eliott, D.; Rosenfeld, P.J.; Gregori, N.Z.; Hubschman, J.P.; Davis, J.L.; Heilwell, G.; Spirn, M., et al. Human embryonic stem cellderived retinal pigment epithelium in patients with age-related macular degeneration and Stargardt's macular dystrophy: follow-up of two open-label phase 1/2 studies. Lancet 2015, 385, 509-516, doi:10.1016/S0140-6736(14)61376-3. 
35. Mandai, M.; Watanabe, A.; Kurimoto, Y.; Hirami, Y.; Morinaga, C.; Daimon, T.; Fujihara, M.; Akimaru, H.; Sakai, N.; Shibata, Y., et al. Autologous Induced Stem-Cell-Derived Retinal Cells for Macular Degeneration. N Engl J Med 2017, 376, 1038-1046, doi:10.1056/NEJMoa1608368.

36. Diniz, B.; Thomas, P.B.; Ribeiro, R.M.; Hu, Y.; Fernandes, R.B.; Ahuja, A.; Zhu, D.; Liu, L.; Koss, M.; Maia, M., et al. Subretinal implantation of retinal pigment epithelial cells derived from human embryonic stem cells - improved survival when implanted as a monolayer. Invest Ophthalmol Vis Sci 2013, 10.1167/iovs.12-11239, doi:10.1167/iovs.12-11239.

37. Wang, S.; Lu, B.; Wood, P.; Lund, R.D. Grafting of ARPE-19 and Schwann cells to the subretinal space in RCS rats. Invest Ophthalmol Vis Sci 2005, 46, 2552-2560, doi:46/7/2552 [pii] 10.1167/iovs.05-0279.

38. Lund, R.D.; Adamson, P.; Sauve, Y.; Keegan, D.J.; Girman, S.V.; Wang, S.; Winton, H.; Kanuga, N.; Kwan, A.S.; Beauchene, L., et al. Subretinal transplantation of genetically modified human cell lines attenuates loss of visual function in dystrophic rats. Proc Natl Acad Sci U S A 2001, 98, 9942-9947, doi:10.1073/pnas.171266298

98/17/9942 [pii].

39. Girman, S.V.; Wang, S.; Lund, R.D. Cortical visual functions can be preserved by subretinal RPE cell grafting in RCS rats. Vision Res 2003, 43, 1817-1827.

40. Coffey, P.J.; Girman, S.; Wang, S.M.; Hetherington, L.; Keegan, D.J.; Adamson, P.; Greenwood, J.; Lund, R.D. Long-term preservation of cortically dependent visual function in RCS rats by transplantation. Nat Neurosci 2002, 5, 53-56, doi:10.1038/nn782 nn782 [pii].

41. Dunn, K.C.; Aotaki-Keen, A.E.; Putkey, F.R.; Hjelmeland, L.M. ARPE-19, a human retinal pigment epithelial cell line with differentiated properties. Exp Eye Res 1996, 62, 155169, doi:S0014-4835(96)90020-2 [pii]

10.1006/exer.1996.0020.

42. Little, C.W.; Castillo, B.; DiLoreto, D.A.; Cox, C.; Wyatt, J.; del Cerro, C.; del Cerro, M. Transplantation of human fetal retinal pigment epithelium rescues photoreceptor cells from degeneration in the Royal College of Surgeons rat retina. Invest Ophthalmol Vis Sci 1996, 37, 204-211.

43. Little, C.W.; Cox, C.; Wyatt, J.; del Cerro, C.; del Cerro, M. Correlates of photoreceptor rescue by transplantation of human fetal RPE in the RCS rat. Exp Neurol 1998, 149, 151-160, doi:10.1006/exnr.1997.6642.

44. Castillo, B.V., Jr.; del Cerro, M.; White, R.M.; Cox, C.; Wyatt, J.; Nadiga, G.; del Cerro, C. Efficacy of nonfetal human RPE for photoreceptor rescue: a study in dystrophic RCS rats. Exp Neurol 1997, 146, 1-9, doi:S0014-4886(97)96534-1 [pii] 10.1006/exnr.1997.6534.

45. Carr, A.J.; Vugler, A.A.; Hikita, S.T.; Lawrence, J.M.; Gias, C.; Chen, L.L.; Buchholz, D.E.; Ahmado, A.; Semo, M.; Smart, M.J., et al. Protective effects of human iPS-derived retinal pigment epithelium cell transplantation in the retinal dystrophic rat. PLOS ONE 2009, 4, e8152, doi:10.1371/journal.pone.0008152.

46. Vugler, A.; Carr, A.J.; Lawrence, J.; Chen, L.L.; Burrell, K.; Wright, A.; Lundh, P.; Semo, M.; Ahmado, A.; Gias, C., et al. Elucidating the phenomenon of HESC-derived RPE: anatomy of cell genesis, expansion and retinal transplantation. Exp Neurol 2008, 214, 347361, doi:10.1016/j.expneurol.2008.09.007.

47. Lu, B.; Malcuit, C.; Wang, S.; Girman, S.; Francis, P.; Lemieux, L.; Lanza, R.; Lund, R. Long-term safety and function of RPE from human embryonic stem cells in preclinical models of macular degeneration. Stem cells (Dayton, Ohio) 2009, 27, 2126-2135, doi:10.1002/stem.149.

48. Lund, R.D.; Wang, S.; Klimanskaya, I.; Holmes, T.; Ramos-Kelsey, R.; Lu, B.; Girman, S.; Bischoff, N.; Sauve, Y.; Lanza, R. Human embryonic stem cell-derived cells rescue visual function in dystrophic RCS rats. Cloning and stem cells 2006, 8, 189-199, doi:10.1089/clo.2006.8.189. 
49. Koster, C.; Wever, K.E.; Wagstaff, P.E.; Van Den Hurk, K.T.; Hooijmans, C.R.; Bergen, A.A. A Systematic Review on Transplantation Studies of the Retinal Pigment Epithelium in Animal Models. International Journal of Molecular Sciences 2020, 21, 2719, doi:10.3390/ijms21082719.

50. Alge, C.S.; Suppmann, S.; Priglinger, S.G.; Neubauer, A.S.; May, C.A.; Hauck, S.; Welge-Lussen, U.; Ueffing, M.; Kampik, A. Comparative proteome analysis of native differentiated and cultured dedifferentiated human RPE cells. Invest Ophthalmol Vis Sci 2003, 44, 3629-3641.

51. Vinores, S.A.; Derevjanik, N.L.; Mahlow, J.; Hackett, S.F.; Haller, J.A.; deJuan, E.; Frankfurter, A.; Campochiaro, P.A. Class III beta-tubulin in human retinal pigment epithelial cells in culture and in epiretinal membranes. Exp Eye Res 1995, 60, 385-400.

52. Carr, A.J.; Smart, M.J.; Ramsden, C.M.; Powner, M.B.; da Cruz, L.; Coffey, P.J. Development of human embryonic stem cell therapies for age-related macular degeneration. Trends Neurosci 2013, 36, 385-395, doi:10.1016/j.tins.2013.03.006.

53. Sheridan, C.; Williams, R.; Grierson, I. Basement membranes and artificial substrates in cell transplantation. Graefes Arch Clin Exp Ophthalmol 2004, 242, 68-75, doi:10.1007/s00417-003-0800-z.

54. Tamiya, S.; Liu, L.; Kaplan, H.J. Epithelial-mesenchymal transition and proliferation of retinal pigment epithelial cells initiated upon loss of cell-cell contact. Invest Ophthalmol Vis Sci 2010, 51, 2755-2763, doi:10.1167/iovs.09-4725.

55. Heller, J.P.; Kwok, J.C.; Vecino, E.; Martin, K.R.; Fawcett, J.W. A Method for the Isolation and Culture of Adult Rat Retinal Pigment Epithelial (RPE) Cells to Study Retinal Diseases. Front Cell Neurosci 2015, 9, 449, doi:10.3389/fncel.2015.00449.

56. Maminishkis, A.; Chen, S.; Jalickee, S.; Banzon, T.; Shi, G.; Wang, F.E.; Ehalt, T.; Hammer, J.A.; Miller, S.S. Confluent monolayers of cultured human fetal retinal pigment epithelium exhibit morphology and physiology of native tissue. Invest Ophthalmol Vis Sci 2006, 47, 3612-3624, doi:47/8/3612 [pii]

10.1167/iovs.05-1622.

57. Sonoda, S.; Spee, C.; Barron, E.; Ryan, S.J.; Kannan, R.; Hinton, D.R. A protocol for the culture and differentiation of highly polarized human retinal pigment epithelial cells. Nature protocols 2009, 4, 662-673, doi:nprot.2009.33 [pii]

10.1038/nprot.2009.33.

58. Ahmado, A.; Carr, A.J.; Vugler, A.A.; Semo, M.; Gias, C.; Lawrence, J.M.; Chen, L.L.; Chen, F.K.; Turowski, P.; da Cruz, L., et al. Induction of differentiation by pyruvate and DMEM in the human retinal pigment epithelium cell line ARPE-19. Invest Ophthalmol Vis Sci 2011, 52, 7148-7159, doi:10.1167/iovs.10-6374.

59. Schindelin, J.; Arganda-Carreras, I.; Frise, E.; Kaynig, V.; Longair, M.; Pietzsch, T.; Preibisch, S.; Rueden, C.; Saalfeld, S.; Schmid, B., et al. Fiji: an open-source platform for biological-image analysis. Nature methods 2012, 9, 676-682, doi:10.1038/nmeth.2019.

60. Vecino, E.; Heller, J.P.; Veiga-Crespo, P.; Martin, K.R.; Fawcett, J.W. Influence of extracellular matrix components on the expression of integrins and regeneration of adult retinal ganglion cells. PLoS One 2015, 10, e0125250, doi:10.1371/journal.pone.0125250.

61. Huang, J.; Possin, D.E.; Saari, J.C. Localizations of visual cycle components in retinal pigment epithelium. Mol Vis 2009, 15, 223-234.

62. Johansson, U.E.; Eftekhari, S.; Warfvinge, K. A battery of cell- and structure-specific markers for the adult porcine retina. $J$ Histochem Cytochem 2010, 58, 377-389, doi:jhc.2009.954933 [pii]

10.1369/jhc.2009.954933.

63. Konari, K.; Sawada, N.; Zhong, Y.; Isomura, H.; Nakagawa, T.; Mori, M. Development of the blood-retinal barrier in vitro: formation of tight junctions as revealed by occludin and ZO1 correlates with the barrier function of chick retinal pigment epithelial cells. Exp Eye Res 1995, 61, 99-108.

64. Campbell, M.; Humphries, P. The blood-retina barrier: tight junctions and barrier modulation. Adv Exp Med Biol 2012, 763, 70-84. 
65. Bakall, B.; Marmorstein, L.Y.; Hoppe, G.; Peachey, N.S.; Wadelius, C.; Marmorstein, A.D. Expression and localization of bestrophin during normal mouse development. Invest Ophthalmol Vis Sci 2003, 44, 3622-3628.

66. Milenkovic, A.; Brandl, C.; Milenkovic, V.M.; Jendryke, T.; Sirianant, L.; Wanitchakool, P.; Zimmermann, S.; Reiff, C.M.; Horling, F.; Schrewe, H., et al. Bestrophin 1 is indispensable for volume regulation in human retinal pigment epithelium cells. Proc Natl Acad Sci U S A 2015, 112, E2630-2639, doi:10.1073/pnas.1418840112.

67. Bharti, K.; Gasper, M.; Ou, J.; Brucato, M.; Clore-Gronenborn, K.; Pickel, J.; Arnheiter, $\mathrm{H}$. A regulatory loop involving PAX6, MITF, and WNT signaling controls retinal pigment epithelium development. PLoS genetics 2012, 8, e1002757, doi:10.1371/journal.pgen.1002757.

68. Capowski, E.E.; Simonett, J.M.; Clark, E.M.; Wright, L.S.; Howden, S.E.; Wallace, K.A.; Petelinsek, A.M.; Pinilla, I.; Phillips, M.J.; Meyer, J.S., et al. Loss of MITF expression during human embryonic stem cell differentiation disrupts retinal pigment epithelium development and optic vesicle cell proliferation. Hum Mol Genet 2014, 23, 6332-6344, doi:10.1093/hmg/ddu351.

69. Hu, J.G.; Gallemore, R.P.; Bok, D.; Lee, A.Y.; Frambach, D.A. Localization of NaK ATPase on cultured human retinal pigment epithelium. Invest Ophthalmol Vis Sci 1994, 35, 3582-3588.

70. Vigneault, F.; Zaniolo, K.; Gaudreault, M.; Gingras, M.E.; Guerin, S.L. Control of integrin genes expression in the eye. Prog Retin Eye Res 2007, 26, 99-161, doi:10.1016/j.preteyeres.2006.10.004.

71. Gullapalli, V.K.; Sugino, I.K.; Zarbin, M.A. Culture-induced increase in alpha integrin subunit expression in retinal pigment epithelium is important for improved resurfacing of aged human Bruch's membrane. Exp Eye Res 2008, 86, 189-200, doi:S0014-4835(07)00302-8 [pii] 10.1016/j.exer.2007.10.009.

72. $\quad$ Brem, R.B.; Robbins, S.G.; Wilson, D.J.; O'Rourke, L.M.; Mixon, R.N.; Robertson, J.E.; Planck, S.R.; Rosenbaum, J.T. Immunolocalization of integrins in the human retina. Invest Ophthalmol Vis Sci 1994, 35, 3466-3474.

73. Sherry, D.M.; Proske, P.A. Localization of alpha integrin subunits in the neural retina of the tiger salamander. Graefes Arch Clin Exp Ophthalmol 2001, 239, 278-287.

74. Anderson, D.H.; Johnson, L.V.; Hageman, G.S. Vitronectin receptor expression and distribution at the photoreceptor-retinal pigment epithelial interface. J Comp Neurol 1995, 360, 1-16, doi:10.1002/cne.903600102.

75. Proulx, S.; Guerin, S.L.; Salesse, C. Effect of quiescence on integrin alpha5beta1 expression in human retinal pigment epithelium. Mol Vis 2003, 9, 473-481, doi:v9/a60 [pii].

76. Proulx, S.; Landreville, S.; Guerin, S.L.; Salesse, C. Integrin alpha5 expression by the ARPE-19 cell line: comparison with primary RPE cultures and effect of growth medium on the alpha5 gene promoter strength. Exp Eye Res 2004, 79, 157-165, doi:10.1016/j.exer.2004.03.004

S0014483504000879 [pii].

77. De Curtis, I. Laminin receptors in the retina: sequence analysis of the chick integrin alpha 6 subunit. Evidence for transcriptional and posttranslational regulation. 1991, 113, 405416, doi:10.1083/jcb.113.2.405.

78. Aisenbrey, S.; Zhang, M.; Bacher, D.; Yee, J.; Brunken, W.J.; Hunter, D.D. Retinal pigment epithelial cells synthesize laminins, including laminin 5, and adhere to them through alpha3- and alpha6-containing integrins. Invest Ophthalmol Vis Sci 2006, 47, 5537-5544.

79. Bossy, B.; Bossy-Wetzel, E.; Reichardt, L.F. Characterization of the integrin alpha 8 subunit: a new integrin beta 1-associated subunit, which is prominently expressed on axons and on cells in contact with basal laminae in chick embryos. EMBO J 1991, 10, 2375-2385.

80. Cann, G.M.; Bradshaw, A.D.; Gervin, D.B.; Hunter, A.W.; Clegg, D.O. Widespread expression of beta1 integrins in the developing chick retina: evidence for a role in migration of retinal ganglion cells. Dev Biol 1996, 180, 82-96, doi:10.1006/dbio.1996.0286. 
81. Lin, H.; Clegg, D.O. Integrin alphavbeta5 participates in the binding of photoreceptor rod outer segments during phagocytosis by cultured human retinal pigment epithelium. Invest Ophthalmol Vis Sci 1998, 39, 1703-1712.

82. Wang, A.G.; Yen, M.Y.; Hsu, W.M.; Fann, M.J. Induction of vitronectin and integrin alphav in the retina after optic nerve injury. Mol Vis 2006, 12, 76-84.

83. Li, R.; Maminishkis, A.; Zahn, G.; Vossmeyer, D.; Miller, S.S. Integrin alpha5beta1 mediates attachment, migration, and proliferation in human retinal pigment epithelium: relevance for proliferative retinal disease. Invest Ophthalmol Vis Sci 2009, 50, 5988-5996, doi:iovs.09-3591 [pii]

10.1167/iovs.09-3591.

84. Gervin, D.B.; Cann, G.M.; Clegg, D.O. Temporal and spatial regulation of integrin vitronectin receptor mRNAs in the embryonic chick retina. Invest Ophthalmol Vis Sci 1996, 37, 1084-1096.

85. Hoffmann, S.; He, S.; Jin, M.; Ehren, M.; Wiedemann, P.; Ryan, S.J.; Hinton, D.R. A selective cyclic integrin antagonist blocks the integrin receptors alphavbeta3 and alphavbeta5 and inhibits retinal pigment epithelium cell attachment, migration and invasion. BMC Ophthalmol 2005, 5, 16, doi:1471-2415-5-16 [pii]

10.1186/1471-2415-5-16.

86. Afshari, F.T.; Kwok, J.C.; Andrews, M.R.; Blits, B.; Martin, K.R.; Faissner, A.; FfrenchConstant, C.; Fawcett, J.W. Integrin activation or alpha 9 expression allows retinal pigmented epithelial cell adhesion on Bruch's membrane in wet age-related macular degeneration. Brain 2010, 133, 448-464, doi:awp319 [pii]

10.1093/brain/awp319.

87. Fang, I.M.; Yang, C.H.; Yang, C.M.; Chen, M.S. Overexpression of integrin alpha6 and beta4 enhances adhesion and proliferation of human retinal pigment epithelial cells on layers of porcine Bruch's membrane. Exp Eye Res 2009, 88, 12-21, doi:S0014-4835(08)00322-9 [pii] 10.1016/j.exer.2008.09.019.

88. Southgate, J.; Kennedy, W.; Hutton, K.A.; Trejdosiewicz, L.K. Expression and in vitro regulation of integrins by normal human urothelial cells. Cell adhesion and communication 1995, 3, 231-242.

89. Baril, P.; Gangeswaran, R.; Mahon, P.C.; Caulee, K.; Kocher, H.M.; Harada, T.; Zhu, M.; Kalthoff, H.; Crnogorac-Jurcevic, T.; Lemoine, N.R. Periostin promotes invasiveness and resistance of pancreatic cancer cells to hypoxia-induced cell death: role of the beta4 integrin and the PI3k pathway. Oncogene 2007, 26, 2082-2094, doi:10.1038/sj.onc.1210009.

90. Devera, C.; Tosini, G. Circadian analysis of the mouse retinal pigment epithelium transcriptome. Experimental Eye Research 2020, 193, 107988, doi:10.1016/j.exer.2020.107988.

91. Kallestad, L.; Blackshaw, S.; Khalil, A.M.; Palczewski, K. Tissue- and Species-Specific Patterns of RNA metabolism in Post-Mortem Mammalian Retina and Retinal Pigment Epithelium. Scientific Reports 2019, 9, doi:10.1038/s41598-019-51379-3.

92. Bennis, A.; Gorgels, T.G.; Ten Brink, J.B.; van der Spek, P.J.; Bossers, K.; Heine, V.M.; Bergen, A.A. Comparison of Mouse and Human Retinal Pigment Epithelium Gene Expression Profiles: Potential Implications for Age-Related Macular Degeneration. PLoS One 2015, 10, e0141597, doi:10.1371/journal.pone.0141597.

93. Suárez-Barrio, C.; Del Olmo-Aguado, S.; García-Pérez, E.; De La Fuente, M.; Muruzabal, F.; Anitua, E.; Baamonde-Arbaiza, B.; Fernández-Vega-Cueto, L.; FernándezVega, L.; Merayo-Lloves, J. Antioxidant Role of PRGF on RPE Cells after Blue Light Insult as a Therapy for Neurodegenerative Diseases. International Journal of Molecular Sciences 2020, 21, 1021, doi:10.3390/ijms21031021.

94. Kanuga, N.; Winton, H.L.; Beauchene, L.; Koman, A.; Zerbib, A.; Halford, S.; Couraud, P.O.; Keegan, D.; Coffey, P.; Lund, R.D., et al. Characterization of genetically modified human retinal pigment epithelial cells developed for in vitro and transplantation studies. Invest Ophthalmol Vis Sci 2002, 43, 546-555. 
95. Janssen, J.J.; Kuhlmann, E.D.; van Vugt, A.H.; Winkens, H.J.; Janssen, B.P.; Deutman, A.F.; Driessen, C.A. Retinoic acid delays transcription of human retinal pigment neuroepithelium marker genes in ARPE-19 cells. Neuroreport 2000, 11, 1571-1579.

96. Alizadeh, M.; Wada, M.; Gelfman, C.M.; Handa, J.T.; Hjelmeland, L.M. Downregulation of differentiation specific gene expression by oxidative stress in ARPE-19 cells. Invest Ophthalmol Vis Sci 2001, 42, 2706-2713.

97. Boulanger, A.; Redmond, T.M. Expression and promoter activation of the Rpe65 gene in retinal pigment epithelium cell lines. Curr Eye Res 2002, 24, 368-375.

98. Delcommenne, M.; Streuli, C.H. Control of integrin expression by extracellular matrix. J Biol Chem 1995, 270, 26794-26801.

99. Wang, X.F.; Cui, J.Z.; Nie, W.; Prasad, S.S.; Matsubara, J.A. Differential gene expression of early and late passage retinal pigment epithelial cells. Exp Eye Res 2004, 79, 209-221, doi:10.1016/j.exer.2004.03.013.

100. Peng, Y.W.; Zallocchi, M.; Meehan, D.T.; Delimont, D.; Chang, B.; Hawes, N.; Wang, W.; Cosgrove, D. Progressive morphological and functional defects in retinas from alpha1 integrin-null mice. Invest Ophthalmol Vis Sci 2008, 49, 4647-4654, doi:10.1167/iovs.08-2011. 101. Rajapakse, D.; Peterson, K.; Mishra, S.; Fan, J.; Lerner, J.; Campos, M.; Wistow, G. Amelotin is expressed in retinal pigment epithelium and localizes to hydroxyapatite deposits in dry age-related macular degeneration. Translational Research 2020, 219, 45-62, doi:10.1016/j.trsl.2020.02.007.

102. Voigt, A.P.; Mulfaul, K.; Mullin, N.K.; Flamme-Wiese, M.J.; Giacalone, J.C.; Stone, E.M.; Tucker, B.A.; Scheetz, T.E.; Mullins, R.F. Single-cell transcriptomics of the human retinal pigment epithelium and choroid in health and macular degeneration. Proceedings of the National Academy of Sciences 2019, 116, 24100-24107, doi:10.1073/pnas.1914143116.

103. Zhang, Z.; Zhang, Y.; Xiao, H.; Liang, X.; Sun, D.; Peng, S. A gene expression profile of the developing human retinal pigment epithelium. Mol Vis 2012, 18, 2961-2975.

104. Kamao, H.; Mandai, M.; Okamoto, S.; Sakai, N.; Suga, A.; Sugita, S.; Kiryu, J.; Takahashi, M. Characterization of Human Induced Pluripotent Stem Cell-Derived Retinal Pigment Epithelium Cell Sheets Aiming for Clinical Application. Stem Cell Reports 2014, 2, 205-218, doi:10.1016/j.stemcr.2013.12.007.

105. Almedawar, S.; Vafia, K.; Schreiter, S.; Neumann, K.; Khattak, S.; Kurth, T.; Ader, M.; Karl, M.O.; Tsang, S.H.; Tanaka, E.M. MERTK-Dependent Ensheathment of Photoreceptor Outer Segments by Human Pluripotent Stem Cell-Derived Retinal Pigment Epithelium. Stem Cell Reports 2020, 14, 374-389, doi:10.1016/j.stemcr.2020.02.004.

106. Berger, A.S.; Kaplan, H.J. Clinical experience with the surgical removal of subfoveal neovascular membranes. Short-term postoperative results. Ophthalmology 1992, 99, 969975; discussion 975-966.

107. Grossniklaus, H.E.; Hutchinson, A.K.; Capone, A., Jr.; Woolfson, J.; Lambert, H.M. Clinicopathologic features of surgically excised choroidal neovascular membranes. Ophthalmology 1994, 101, 1099-1111.

108. Lopez, P.F.; Grossniklaus, H.E.; Lambert, H.M.; Aaberg, T.M.; Capone, A., Jr.; Sternberg, P., Jr.; L'Hernault, N. Pathologic features of surgically excised subretinal neovascular membranes in age-related macular degeneration. Am J Ophthalmol 1991, 112, 647-656.

109. Castellarin, A.A.; Nasir, M.A.; Sugino, I.K.; Zarbin, M.A. Clinicopathological correlation of primary and recurrent choroidal neovascularisation following surgical excision in age related macular degeneration. $\mathrm{Br} J$ Ophthalmol 1998, 82, 480-487.

110. Del Priore, L.V.; Tezel, T.H.; Kaplan, H.J. Maculoplasty for age-related macular degeneration: reengineering Bruch's membrane and the human macula. Prog Retin Eye Res 2006, 25, 539-562, doi:S1350-9462(06)00030-9 [pii]

10.1016/j.preteyeres.2006.08.001.

111. Nicolo, M.; Piccolino, F.C.; Zardi, L.; Giovannini, A.; Mariotti, C. Detection of tenascin$\mathrm{C}$ in surgically excised choroidal neovascular membranes. Graefes Arch Clin Exp Ophthalmol 2000, 238, 107-111. 
bioRxiv preprint doi: https://doi.org/10.1101/2020.06 26.133553. this version posted June 27 2020. The copyright holder for this preprint (which was not certified by peer review) is the author/funder, who has granted bioRxiv a license to display the preprint in perpetuity. It is made available under aCC-BY-NC-ND 4.0 International license.

112. Fasler-Kan, E.; Wunderlich, K.; Hildebrand, P.; Flammer, J.; Meyer, P. Activated STAT 3 in choroidal neovascular membranes of patients with age-related macular degeneration. Ophthalmologica 2005, 219, 214-221, doi:OPH2005219004214 [pii] 10.1159/000085730.

113. Al Gwairi, O.; Thach, L.; Zheng, W.; Osman, N.; Little, P.J. Cellular and Molecular Pathology of Age-Related Macular Degeneration: Potential Role for Proteoglycans. Journal of ophthalmology 2016, 2016, 2913612, doi:10.1155/2016/2913612.

114. Varnum-Finney, B.; Venstrom, K.; Muller, U.; Kypta, R.; Backus, C.; Chiquet, M.; Reichardt, L.F. The integrin receptor alpha 8 beta 1 mediates interactions of embryonic chick motor and sensory neurons with tenascin-C. Neuron 1995, 14, 1213-1222, doi:08966273(95)90268-6 [pii].

115. Schnapp, L.M.; Hatch, N.; Ramos, D.M.; Klimanskaya, I.V.; Sheppard, D.; Pytela, R. The human integrin alpha 8 beta 1 functions as a receptor for tenascin, fibronectin, and vitronectin. J Biol Chem 1995, 270, 23196-23202.

116. Ho, T.C.; Del Priore, L.V. Reattachment of cultured human retinal pigment epithelium to extracellular matrix and human Bruch's membrane. Invest Ophthalmol Vis Sci 1997, 38, 1110-1118.

117. Chu, P.G.; Grunwald, G.B. Functional inhibition of retinal pigment epithelial cellsubstrate adhesion with a monoclonal antibody against the beta 1 subunit of integrin. Invest Ophthalmol Vis Sci 1991, 32, 1763-1769.

118. Hergott, G.J.; Nagai, H.; Kalnins, V.I. Inhibition of retinal pigment epithelial cell migration and proliferation with monoclonal antibodies against the beta 1 integrin subunit during wound healing in organ culture. Invest Ophthalmol Vis Sci 1993, 34, 2761-2768. 
bioRxiv preprint doi: https://doi org/10.1101/2020.06.26.133553: this version posted June 27.2020 . The copyright holder for this preprint (which was not certified by peer review) is the author/funder, who has granted bioRxiv a license to display the preprint in perpetuity. It is made available under aCC-BY-NC-ND 4.0 International license.

Table 1: Primary antibodies used.

All antibodies are IgG. RRID = Research Resource Identifier.

\begin{tabular}{|l|l|l|l|l|l|}
\hline Antigen & Host & clone & Supplier & product code & RRID \\
\hline BEST & mouse & monoclonal & Millipore & MAB5466 & AB_2064603 \\
\hline CRALBP & mouse & B2 & Novus & NB100-74392 & AB_1048601 \\
\hline Cytokeratin 18 & mouse & C-04 & Abcam & ab668 & AB_305647 \\
\hline integrin $\alpha 1$ & rabbit & polyclonal & Millipore & AB1934 & AB_91199 \\
\hline integrin $\alpha 2$ & rabbit & polyclonal & Millipore & AB1936 & AB_2265143 \\
\hline integrin $\alpha 3$ & rabbit & polyclonal & Millipore & AB1920 & AB_11213115 \\
\hline integrin $\alpha 4$ & rabbit & polyclonal & Millipore & AB1924 & AB_91181 \\
\hline integrin $\alpha 5$ & rabbit & polyclonal & Millipore & AB1928 & AB_2128185 \\
\hline integrin $\alpha 6$ & rat & GoH3 & BD Pharmingen & 555734 & AB_2296273 \\
\hline integrin $\alpha 8$ & rabbit & polyclonal & Santa Cruz & sc-25713 & AB_2265044 \\
\hline integrin $\alpha V$ & rabbit & polyclonal & Millipore & AB1930 & AB_11213475 \\
\hline integrin $\beta 1$ & rabbit & polyclonal & Millipore & AB1952 & AB_91150 \\
\hline integrin $\beta 3$ & rabbit & polyclonal & Millipore & AB2984 & AB_10806204 \\
\hline integrin $\beta 4$ & rabbit & polyclonal & Millipore & AB1922 & AB_91186 \\
\hline integrin $\beta 5$ & rabbit & polyclonal & Millipore & AB1926 & AB_91119 \\
\hline integrin $\alpha V \beta 3$ & mouse & $27.1(V N R-1)$ & abcam & ab78289 & AB_1566022 \\
\hline integrin $\alpha V \beta 5$ & mouse & P1F6 & abcam & ab24694 & AB_448231 \\
\hline MiTF & mouse & C5 & abcam & ab12039 & AB_298801 \\
\hline Na ${ }^{/} \mathrm{K}^{+}$ATPase & mouse & C464.8 & Millipore & $05-382$ & AB_309708 \\
\hline RPE65 & mouse & $401.8 B 11.3 D 9$ & Millipore & MAB5428 & AB_571111 \\
\hline ZO-1 & rabbit & polyclonal & Thermo Fisher & $61-7300$ & AB_138452 \\
\hline
\end{tabular}

Table 2: Secondary antibodies used.

All antibodies are polyclonal and were purchased from Thermo Fisher. RRID = Research Resource Identifier.

\begin{tabular}{|l|l|l|l|l|}
\hline Antigen & Feature & Host & product code & RRID \\
\hline mouse IgG & Alexa488-fluorochrome conjugated & donkey & A-21202 & AB_141607 \\
\hline mouse IgG & Alexa568-fluorochrome conjugated & donkey & A-10037 & AB_2534013 \\
\hline rabbit IgG & Alexa488-fluorochrome conjugated & donkey & A-21206 & AB_141708 \\
\hline rabbit IgG & Alexa568-fluorochrome conjugated & donkey & A-10042 & AB_2534017 \\
\hline rat IgG & Alexa488-fluorochrome conjugated & goat & A-11006 & AB_2534074 \\
\hline
\end{tabular}

